\title{
PARTISIPASI MASYARAKAT DALAM PENGEMBANGAN KAMPUNG WISATA KREATIF DAGO POJOK
}

\author{
Oleh: \\ Berry Choresyo, Soni A. Nulhaqim, Hery Wibowo \\ choresyoberry@gmail.com,soni.nulhaqim@unpad.ac.id,hery.wibowo@unpad.ac.id
}

\begin{abstract}
ABSTRAK
Penelitian ini berjudul "Partisipasi Masyarakat Dalam Pengembangan Kampung Wisata Dago Pojok". Penelitian ini akan mencoba untuk mendeskripsikan bagaimana partisipasi masyarakat di RW 03 terhadap program kampung wisata kreatif Dago Pojok dilihat dari prasyarat partisipasi yaitu kesempatan, kemampuan dan keinginan dan jenis partisipasi yang terbagi menjadi 5 (lima) jenis antara lain pemikiran, tenaga, keahlian, barang dan uang.

Metode penelitian yang digunakan adalah metode deskriptif dengan pendekatan kualitatif dan teknik yang digunakan pada pennelitian ini adalah studi kasus. Data yang dihasilkan adalah data kualitatif yang diambil dari hasil wawancara, observasi, dan studi dokumentasi. Informan dalam penelitian ini terdiri dari 8 (delapan) orang yang dianggap dapat memberikan informasi terperinci mengenai partisipasi masyarakat RW 03 dalam program kampung wisata kreatif.

Hasil penelitian yang didapat menunjukkan bahwa aspek-aspek prasyarat partisipasi yaitu kesempatan, kemampuan dan keinginan telah terpenuhi. Dengan begitu, partisipasi dalam berbagai jenis dapat terwujud dari masyarakat. Melihat dari jenis partisipasi, warga telah melaksanakan kelima jenis partisipasi yang terdiri dari partisipasi pemikiran, tenaga, keahlian, barang dan uang. Meskipun masih ada kekurangan dalam hal partisipasi uang, hal tersebut dikarenakan masih kurangnya kemampuan warga untuk memberikan partisipasi uang dan belum adanya sistem yang mengatur pendanaan program dari uang warga.

Berdasarkan pada hasil penelitian, saran yang diberikan oleh peneliti adalah penguatan sumber dana untuk program kampung wisata kreatif. Tujuan dari kegiatan ini adalah untuk menutupi kekurangan warga secara individu untuk memberikan partisipasi uang dan memperkuat sumber pendanaan kampung wisata kreatif.
\end{abstract}

\section{Kata Kunci: Partisipasi Masyarakat, Pengembangan Kampung Wisata Kreatif}

\section{PENDAHULUAN}

Kampung kota merupakan wilayah yang dekat dengan berbagai permasalahan seperti kemiskinan yang dapat memicu kriminalitas, kondisi sosial dan lingkungan yang kurang baik serta atmosfer masyarakat yang negatif. Hal ini dapat dilihat dari Kondisi sosial ekonomi masyarakat yang berada di kawasan perkampungan kota mencakup tingkat pendapatan rendah, norma sosial yang longgar, budaya kemiskinan yang mewarnai kehidupannya yang antara lain tampak dari sikap dan perilaku yang apatis (Budiharjo:1992). Berbagai program dan kegiatan yang bertujuan untuk mengembangkan potensi masyarakat kampung kota telah dilaksanakan di berbagai wilayah. Salah satu contoh program yang memiliki 
tujuan tersebut adalah program Kampung Kreatif yang dilaksanakan di wilayah RW 03 Jalan Dago Pojok, Coblong, Bandung. Kampung Wisata Kreatif Dago Pojok memiliki konsep berupa wisata, edukasi dan industri dengan tujuan untuk mengangkat potensi daerah perkampungan sebagai pusat kegiatan ekonomi dan budaya (Chairunisa, 2012). Kampung wisata kreatif merupakan salah satu contoh dari Pariwisata berbasis masyarakat (Community Based Tourism) yang mana perkembangan dan pengelolaannya dikontrol oleh masyarakat lokal, dimana bagian terbesar dari manfaat yang dihasilkan kepariwisataan tersebut dinikmati oleh masyarakat lokal, baik yang terlibat secara langsung maupun tidak langsung dalam kepariwisataan tersebut. (Hausler dan Stradas, 2003:3). Melihat dari prinsipnya, Konsep Pariwisata Berbasis Masyarakat juga termasuk kedalam pengembangan masyarakat lokal (Locality Development) sebagaimana yang diungkapkan Rothman (1968) (dalam Suharto, 2009):

"Pengembangan masyarakat lokal (Locality Development) merupakan proses yang ditujukan untuk menciptakan kemajuan sosial dan ekonomi bagi masyarakat melalui partisipasi aktif serta inisiatif anggota masyarakat itu sendiri. Anggota masyarakat dipandang bukan sebagai sistem klien yang bermasalah melainkan sebagai masyarakat yang unik dan memiliki potensi, hanya saja potensi tersebut belum sepenuhnya dikembangkan."

Berdasarkan pemaparan tersebut terlihat bahwa Pengembangan masyarakat merupakan kegiatan pembangunan dimana masyarakat itu sendiri memiliki peran yang sangat penting dalam terwujudnya keberhasilan dan tercapainya tujuan dari suatu program pembangunan karena masyarakat lah yang memiliki potensi dan partisipasi aktif dari masyarakat dalam menciptakan aktivitas atau kegiatan yang bertujuan untuk mengembangkan potensi tersebut merupakan suatu proses untuk mewujudkan tujuan dari pengembangan masyarakat. Pentingnya Peran serta aktif masyarakat dalam program pengembangan masyarakat juga disebutkan dalam pengertian Pengembangan Masyarakat (Community Development) menurut PBB (1955):

"Pengembangan masyarakat didefinisikan sebagai suatu proses yang dirancang untuk menciptakan kemajuan kondisi ekonomi dan sosial bagi seluruh warga masyarakat dengan partisipasi aktif dan sejauh mungkin menumbuhkan prakarsa masyarakat itu sendiri."

Dalam sebuah program pengembangan masyarakat seperti Kampung Kreatif, keikutsertaan masyarakat merupakan hal yang sangat penting untuk mewujudkan perubahan yang dikehendaki melalui program tersebut. Sebagaimana tujuan dalam pengembangan masyarakat hanya bisa tercapai apabila ada partisipasi penuh dari masyarakat. Proses pengembangan masyarakat juga tidak dapat dipaksakan dari luar dan tidak dapat ditentukan oleh pekerja masyarakat, dewan perwakilan ataupun instansi pemerintahan. Proses pengembangan masyarakat adalah suatu proses yang harus dilaksanakan dan dikuasai oleh masyarakat itu sendiri (Ife, 2006:348,349). Keikutsertaan warga dalam pengembangan program Kampung Wisata Kreatif Dago Pojok dapat terlihat adanya dari kegiatan-kegiatan yang dilaksanakan, seperti pentas kesenian yang dibuat oleh warga setempat dan berbagai kegiatan pelatihan kesenian dan keterampilan yang rutin diadakan oleh warga setempat yang dapat menjadi nilai jual wilayah tersebut sebagai kampung wisata. Pengembangan kampung wisata kreatif di dago Pojok dapat berjalan dengan baik apabila partisipasi masyarakat terwujud dan memberikan berbagai jenis sumbangan untuk mendorong pengembangannya. Oleh karena itu, akan diteliti lebih terperinci lagi mengenai bagaimana terjadinya partisipasi masyarakat dan partisipasi seperti apa yang diberikan warga setempat dalam pengembangan Kampung Wisata Kreatif Dago Pojok 


\section{Permasalahan}

Berdasarkan pembahasan pada pendahuluan, maka ruang lingkup pembahasan dalam penelitian ini dapat diidentifikasi sebagai berikut :

Berdasarkan latar belakang yang telah diuraikan sebelumnya, maka dapat dirumuskan masalah penelitiannya yaitu:

1. Bagaimana Prasyarat terjadinya partisipasi masyarakat RW 03 Dago Pojok dalam pegembangan Kampung Wisata Kreatif Dago Pojok?

2. Bagaimana Jenis Partisipasi yang diberikan masyarakat RW 03 Dago Pojok dalam Pengembangan Kampung Wisata Kreatif Dago Pojok?

\section{Metode Penelitian}

Metode yang digunakan adalah metode penelitian deskriptif dengan pendekatan kualitatif yang dapat digunakan untuk memperoleh informasi dan memberikan gambaran sebuah penelitian. Nazir (2003) mengungkapkan metode deskriptif sebagai: "Suatu metode dalam meneliti status kelompok manusia, suatu objek, suatu set kondisi, suatu sistem pemikiran ataupun suatu kelas peristiwa pada masa sekarang. Tujuan dari penelitian deskriptif adalah untuk membuat deskripsi, gambaran atau lukisan secara sistematis, faktual, dan akurat mengenai fakta-fakta, sifatsifat serta hubungan antara fenomena yang diselidiki". Metode deskriptif dengan pendekatan kualitatif digunakan dalam penelitian ini untuk mendapatkan data yang lebih terperinci dan mendalam, bukan sekedar data yang telah ada. Sehingga dapat dijadikan sebuah pelajaran dan pembelajaran untuk hasil positif dan negatifnya dapat jelas terlihat, sehingga partisipasi masyarakat dalam pengembangan kampung kreatif di Dago Pojok dapat tergambarkan dengan baik, jelas dan akurat. Dalam penelitian ini penulis ingin menggambarkan secara mendalam tentang Partisipasi masyarakat dalam pengembangan kampung kreatif Dago Pojok, sehingga teknik yang digunakan adalah studi kasus. Penelitian ini tidak hanya bertujuan untuk menggambarkan seperti apa partisipasi yang diberikan oleh masyarakat, namun juga mengetahui lebih mendalam lagi bagaimana partisipasi itu terjadi dan menggambarkan lebih terperinci hal-hal yang berkaitan dengan fenomena partisipasi masyarakat. Oleh karena itu, dengan teknik studi kasus, segala aspek yang berhubungan dengan fenomena partisipasi masyrakat dan segala hal berhubungan yang dapat menggambarkan fenomena, dapat tereksplorasi dengan baik dan memberikan gambaran yang kuat untuk fenomena partisipasi masyarakat dalam pengembangan kampung wisata kreatif Dago Pojok. Pertimbangan ini berdasar pada informan yang dianggap mengetahui dan paham tentang fenomena yang bersangkutan dengan hal yang hendak diteliti. Dengan begitu, penjelajahan situasi objek sosial akan lebih mudah diteliti dengan bantuan informasi dari informan di lapangan yang memang mengetahui. Purposive Sampling merupakan pemilihan siapa subjek yang ada dalam posisi terbaik untuk memberikan informasi yang dibutuhkan (Ulber Silalahi 2009 :272). Informan yang dipilih dalam penelitian ini ditentukan oleh keterlibatan dan mempunyai pengetahuan yang cukup luas dan ikut terlibat dalam kegiatan-kegiatan di Kampung Wisata Kreatif. Dengan begitu informasi yang diperoleh dari informan, dapat membantu penelitian ini menjadi lebih jelas, terperinci dan akurat. Teknik pengumpulan data yang digunakan adalah wawancara mendalam, observasi nonpartisipasi, studi kepustakaan dan studi dokumentasi. Teknik analisis data yang digunakan adalah reduksi data, penyajian data (display data), dan penarikan kesimpulan. Informan adalah orang yang dimanfaatkan untuk memberikan informasi tentang situasi dan kondisi latar belakang penelitian. Di samping itu pemanfaatan informan bagi peneliti adalah agar dalam waktu yang relatif singkat dapat memperoleh informasi yang dibutuhkan. Informan dimanfaatkan untuk berbicara, bertukar pikiran, atau membandingkan suatu kejadian yang ditemukan dari subjek lainnya. Dalam penelitian ini informan yang dipilih merupakan individu-individu yang dianggap mewakili 
pengurus program, warga dan tokoh masyarakat.

\section{Hasil Penelitian}

Pada bagian ini akan dijelaskan hasil penelitian yang telah diperoleh di lapangan melalui observasi dan wawancara mendalam terkait aspek dan fokus penelitian yang telah dipaparkan pada bab dua yaitu prasyarat partisipasi yang diberikan program sehingga dapat terciptanya partisipasi masyarakat dan jenis partisipasi yang diberikan oleh warga untuk mendukung pengembangan program kampung kreatif di RW 03 Dago Pojok.

\section{Prasyarat Partisipasi}

Pada bagian ini akan dipaparkan hasil penelitian mengenai prasyarat partisipasi masyarakat yang akan menjelaskan apakah ada kesempatan untuk berpartisipasi yang diberikan dari program dan kesempatan dari warga itu sendiri untuk berpartisipasi, kemampuan warga sehingga mereka dapat memberikan keterlibatannya dalam pengembangan program dan yang terakhir keinginan warga untuk terlibat dalam kegiatan pengembangan program.

\section{a. Kesempatan Masyarakat}

Pada kampung wisata kreatif Dago Pojok, kesempatan masyarakat untuk berpartisipasi diberikan sejak awal kampung kreatif digagas. Berdasarkan informasi yang didapat dari pihak penggagas program, konsep kampung wisata kreatif yang akan diterapkan di RW 03 pertama-tama diusulkan dulu kepada para tokoh masyarakat lalu kemudian menawarkan konsep tersebut kepada masyarakat melalui sosialisasi. Warga setempat diberikan informasi mengenai program kampung kreatif dan diberikan penjelasan mengenai bagaimana mereka dapat berperan dalam pengembangan program yang nantinya dapat memberikan dampak positif untuk wilayah mereka. Dalam pengembangan program kampung kreatif, warga memiliki kesempatan untuk menjadi pengurus program sebagaimana program kampung kreatif memang dibuat untuk dikelola oleh masyarakat itu sendiri. Kegiatan- kegiatan yang dilaksanakan oleh kampung kreatif banyak juga melibatkan warga setempat yang tidak ikut kedalam kepengurusan program.

Selain dari kesempatan yang diberikan oleh program, harus dilihat juga apakah masyarakat memiliki waktu dan kesempatan dari mereka sendiri untuk dapat berpartisipasi. Pada kampung kreatif Dago Pojok, sebagian dari warga hanya memiliki kesempatan waktu untuk memberikan keterlibatannya pada saatsaat tertentu saja seperti pada sore hari atau hari libur karena sebagian dari mereka memiliki kesibukan dengan pekerjaannya masing-masing sementara pemuda di RW 03 memiliki lebih banyak waktu untuk aktif memberikan keterlibatan dalam pengembangan kampung kreatif karena banyak dari mereka masih sekolah atau belum memiliki pekerjaan tetap. Untuk mewujudkan partisipasi masyarakat, kesempatan untuk berpartisipasi juga harus tersedia dari masyarakat itu sendiri. Seperti contohnya, apabila program telah memberikan banyak akses untuk berpartisipasi, warga juga harus memiliki waktu untuk berpartisipasi melalui kesempatan yang telah disediakan.

\section{b. Kemampuan Masyarakat}

Kemampuan masyarakat untuk berpartisipasi dilihat dari adanya kemampuan masyarakat secara fisik, mental maupun materi untuk dapat mendukung program. Jika melihat pada kemampuan fisik, berdasarkan hasil observasi yang didapatkan, Warga RW 03 banyak yang berada di usia produktif kerja yaitu usia 15-64 tahun, dan mayoritas warga masih memiliki kemampuan fisik untuk aktif bekerja sehariharinya. Melihat dari hal tersebut, sudah sewajarnya apabila warga RW 03 dapat bekerja untuk membantu pengembangan kampung kreatif. Mayoritas dari warga RW 03 juga memiliki kondisi tubuh yang sehat serta tidak cacat dan warga masih sanggup melaksanakan kegiatan seperti kerja bakti atau hadir dalam pertemuan-pertemuan RW. Sehingga sudah sewajarnya apabla tidak ada kesulitan bagi mereka untuk berpartisipasi 
membantu aktivitas pengembangan program yang berhubungan dengan kemampuan fisik. Kemampuan mental dapat dilihat dari keahlian masyarakat yang berhubungan dengan mental atau pikiran dan kemampuan untuk berinteraksi dengan baik, di RW 03 Dago Pojok, banyak warga yang memiliki berbagai macam keahlian yang melibatkan pikiran dan mentalitas mereka dapat seperti misalnya, warga yang merupakan seniman serta yang bekerja sebagai pengrajin memiliki keahlian dibidang kesenian. Kemampuan dan pengertian mereka pada bidang tersebut dapat mendukung program kampung kreatif dalam merancang dan membuat produk wisatanya. Beberapa warga juga memiliki kemampuan untuk mengelola kegiatan atau program bersama-sama dengan berbekal pengalaman warga bekerja di berbagai tempat. Beberapa warga bekerja di luar Dago Pojok dan karena sudah terbiasa dengan lingkungan pekerjaan, banyak warga juga sudah tidak asing dengan aktivitas keorganisasian. Tingkat pendidikan warga RW 03 mayoritas hanya sampai sekolah menengah dan ada beberapa yang sarjana. Latar belakang pendidikan dan pengalaman bekerja warga telah membentuk kemampuan berpikir warga dalam menghadapi masalah dan menangani berbagai macam situasi pada masyarakat dan dapat menjadi potensi bagi mereka untuk memberikan partisipasi dalam pengembangan program. Kemampuan warga secara mental juga dapat dilihat dari bagaimana interaksi antar warga.

Kemampuan materi warga dapat dilihat dari tingkat ekonomi nya. Mayoritas warga RW 03 berada pada tingkat ekonomi menengah kebawah, namun masih ada beberapa warga yang memiliki aset di wilayah Dago Pojok seperti tanah, rumah atau kendaraan dan ada sedikit warga dengan tingkat ekonomi menengah keatas.

\section{c. Keinginan Masyarakat}

Selain dari kesempatan dan kemampuan yang dimiliki masyarakat, salah satu hal penting yang menjadi prasyarat terjadinya partisipasi masyarakat dalam suatu program pembangunan adalah adanya keinginan dari masyarakat. Adanya keinginan yang kuat dari masyarakat dapat mendorong masyarakat mengembangkan kemampuan yang dimilikinya untuk memberikan kontribusi positif kepada program pembangunan. Pada kampung kreatif Dago Pojok, masyarakat RW 03 memiliki keinginan akan adanya perubahan positif untuk wilayah kampung Dago Pojok, kebanyakan dari mereka sudah lama tinggal di Dago pojok dan memiliki keinginan supaya wilayahnya maju dan berkembang. Warga memiliki keinginan agar aktivitas kesenian di wilayah RW 03 yang sudah ada sejak dulu dapat menarik perhatian masyarakat luar sehingga wilayah mereka banyak didatangi pengunjung. Banyaknya pengunjung yang datang ke Dago Pojok dianggap warga dapat membantu perekonomian mereka dan membuat kampung mereka jadi dipedulikan oleh banyak orang. Warga juga memiliki keinginan untuk ikut berpartisipasi karena mereka menganggap dengan berpartisipasi dalam program kampung kreatif bersama dengan warga yang lain juga dapat mempererat kebersamaan warga sehingga menciptakan hubungan yang baik antar sesama warga. Sebelum adanya program yang mereka laksanakan bersama, warga RW 03 banyak yang tidak mengenal satu sama lain, karena itulah ada keinginan dari warga untuk menyatukan dan meningkatkan kebersamaan warga RW 03 dengan sama-sama terlibat dalam pengembangan program kampung kreatif. Warga di Dago Pojok juga memiliki keinginan untuk terlibat dalam aktivitasaktivitas pengembangan program karena ada keinginan mereka untuk belajar dan mengambil manfaat bagi pengembangan diri mereka apabila mereka ikut serta dalam kegiatan-kegiatan program.

Sejauh program kampung kreatif berjalan saat penelitian ini dilakukan, Warga merasa sudah ada perubahan positif yang mereka rasakan terjadi sejak program kampung kreatif dijalankan di RW 03. Seperti misalnya, kegiatan kesenian menjadi berkembang sehingga anak-anak, remaja dan pemuda memiliki kegiatan positif di waktu luangnya beberapa warga khususnya seniman 
dan pengrajin lokal di Dago Pojok juga merasa senang dengan konsep pembangunan kampung kreatif yang bertujuan untuk memberdayakan masyrakat melalui kesenian. Hal tersebut membuat mereka memiliki keinginan yang besar untuk ikut memberikan kontribusi demi berhasilnya program kampung kreatif Dago Pojok. Kegiatan-kegiatan kampung kreatif Dago Pojok yang selalu melibatkan warga dari setiap RT di RW 03 juga memberi dampak yang baik karena dengan kerukunan dan solidaritas antar warga semakin meningkat. Para pengrajin dan seniman lokal pun jadi semakin terberdayakan setelah wilayah RW 03 mulai dikenal sebagai kampung wisata kreatif karena hal tersebut mengundang banyak peminat kesenian dari dalam maupun luar negeri untuk memesan hasil karya mereka dalam jumlah yang banyak. Beberapa manfaat positif yang dirasakan warga dari program kampung wisata kreatif tersebut semakin memacu keinginan warga untuk ikut terlibat dalam setiap kegiatan pengembangan kampung wisata kreatif Dago Pojok karena warga ingin program tersebut terus berjalan dan memberikan dampak baik yang dapat terjadi namun masih belum dapat terwujud sampai saat penelitian ini dilakukan . Seperti contohnya tersedianya pusat ekonomi kreatif warga di RW 03 dan jumlah kunjungan wisatawan yang dapat mencapai ratusan dalam satu harinya yang dapat membuat wilayah RW 03 Dago Pojok benar-benar menjadi kampung wisata yang menjadi pusat perekonomian, budaya dan edukasi bagi warga setempat. Keinginan warga untuk mewujudkan hal-hal tersebut lah yang menjadi dasar alasan mengapa mereka mau ikut terlibat memberikan kontribusinya untuk mendukung pengembangan kampung wisata kreatif dengan segala jenis partisipasi yang dapat mereka berikan sejalan dengan kemampuan dan kesempatan untuk berpartisipasi yang mereka miliki.

\section{Jenis Partisipasi}

\section{a. Partisipasi Pemikiran}

Partisipasi masyarakat dengan pemikiran merupakan jenis partisipasi yang diberikan masyarakat dengan bentuk memberikan pendapat yang konstruktif, gagasan, usulan, dan kritik dalam pengembangan kampung wisata kreatif. Partisipasi pemikiran dalam pengembangan kampung wisata kreatif diwadahi dalam sebuah rapat besar yang diadakan oleh pengurus setiap sebulan sekali untuk mengevaluasi perkembangan program kampung wisata kreatif dan menentukan kegiatan-kegiatan atau agenda yang akan dilaksanakan berikutnya. Dalam rapat tersebut pengurus memperbolehkan siapapun warga yang ingin datang dan memberikan partisipasi pemikiran. Rapat bulanan yang diadakan oleh pengurus juga diadakan di ruang terbuka, dengan begitu warga yang bukan pengurus dapat dengan mudah datang dan ikut memberikan pendapat maupun masukannya. Dalam rapat tersebut warga dapat memberikan evaluasi mengenai perkembangan program selama satu bulan dan dapat memberi masukan atau usulan mengenai agenda yang harus dijalankan berikutnya untuk mengembangkan kampung wisata kreatif.

Warga juga biasa memberikan pendapat secara informal ketika bertemu dengan pengurus. Berdasarkan informasi dari salah seorang informan, saat memiliki waktu luang warga sering duduk-duduk ngobrol bareng dan pembicaraan pun akhirnya mengarah kepada pembicaraan tentang program kampung kreatif. Dari pembicaraan santai tersebut biasanya muncul gagasangagasan untuk agenda kampung wisata kreatif berikutnya. Seperti misalnya salah seorang warga pernah memiliki pemikiran untuk mengajak anak-anak ikut serta dalam sebuah pementasan di kampung wisata lalu kemudian warga tersebut mengusulkan kepada ketua program untuk menggelar festival permainan anak-anak yang kemudian dilaksanakan setelah ide tersebut didiskusikan bersama dengan pengurus dan warga lain. Selain itu, saat wilayah RW 03 sedang sempat mengalami permasalahan kesulitan air akibat kekeringan, salah seorang warga mengusulkan kepada pengurus secara informal untuk mengajak warga melakukan tindakan sadar hemat air 
melalui kegiatan kesenian, usulan tersebut pun di respon dengan dibuatnya pameran kesenian yang bertemakan air. Dapat dilihat bagaimana partisipasi pemikiran oleh warga dapat terjadi melalui situasi formal seperti melalui rapat dan juga informal. Baik melalui cara formal atau informal, warga dapat memberikan ide atau gagasan yang dapat ditindaklanjuti menjadi suatu kegiatan di wilayah kampung wisata kreatif Dago Pojok.

Dari beberapa contoh tersebut dapat diketahui bahwa warga RW 03 Dago Pojok memberikan partisipasi pemikiran berupa masukan, saran dan juga kritikan yang disampaikan melalui rapat atau diskusi bersama dengan pengurus dan terlihat juga bagaimana partisipasi pemikiran dari warga menjadi acuan dari pengembangan kampung wisata kreatif. Menurut salah seorang informan yang merupakan pengurus program, pendapat dan masukan terhadap program kampung wisata kreatif sudah sewajibnya diberikan oleh warga dan diharapkan oleh pengurus karena program dibuat untuk warga dan berjalan apabila warga memiliki antusiasme terhadap program dan program harus mengetahui pendapat warga supaya langkah-langkah yang diambil oleh program sesuai dengan kebutuhan dan keinginan warga. Dapat dilihat bagaimana partisipasi pemikiran warga pada pengembangan kampung wisata kreatif Dago Pojok tidak hanya diperlukan untuk memberikan ide-ide dalam pembuatan konsep kegiatan yang diadakan, namun juga diperlukan sebagai petunjuk agar arah pengembangan kampung wisata kreatif sesuai dengan apa yang dibutuhkan oleh warga.

\section{b. Partisipasi Tenaga}

Selain partisipasi dalam bentuk pemikiran, partisipasi dalam bentuk tenaga juga dapat diberikan dalam pengembangan kampung kreatif Dago Pojok. Menurut Hamijoyo (2007:21), partisipasi tenaga adalah partisipasi yang diberikan dalam bentuk tenaga untuk pelaksanaan usaha-usaha yang dapat menunjang keberhasilan suatu program. Dalam pengembangan kampung kreatif Dago Pojok, partisipasi tenaga merupakan partisipasi yang paling banyak diberikan oleh warga karena hampir seluruh warga dapat memberikan partisipasi tenaga. Seorang informan yang merupakan salah satu tokoh masyarakat, mengatakan warga yang dari kalangan tua yang bukan seniman biasanya tidak banyak memberikan keterlibatan dalam kegiatan kesenian ataupun ikut hadir dalam rapat maupun diskusi untuk memberikan ideide atau saran untuk pengembangan program, tapi jika dalam persiapan dan pelaksanaan acara dibutuhkan bantuan tenaga, tanpa diminta pun kadang warga menawarkan bantuan dengan sendirinya. Partisipasi tenaga yang diberikan warga RW 03 untuk mendukung pengembangan kampung kreatif Dago Pojok dapat dilihat pada saat kampung kreatif Dago Pojok sedang mengadakan pementasan atau pelatihan seni. Persiapan teknis acara seperti misalnya pembuatan panggung, dekorasi kampung dan persiapan properti lainnya dilaksanakan secara bergotong royong baik oleh warga yang ikut kedalam kepanitiaan acara tersebut maupun yang tidak. Warga yang menjadi panitia dalam acara tersebut biasanya adalah dari kalangan muda dan banyak berperan dalam pengkosepan acara dan penjalinan kerja sama dengan lembaga atau instansi yang dapat membantu berjalannya acara di kampung kreatif melalui pemberian sponsor atau pembuatan liputan. Sementara warga dari kalangan tua biasanya tidak banyak yang ikut dalam kepanitiaan karena sudah memiliki kesibukan dalam pekerjaan dan keluarga, namun beberapa tetap menghadiri rapat bulanan dan diskusi mengenai konsep saat merka punya waktu. Karena itulah kepanitiaan acara di kampung kreatif lebih banyak diikuti orang-orang muda. Namun warga yang sudah memiliki kesibukan pun tetap ikut membantu dalam persiapan dan kelangsungan acara, seperti misalnya warga yang sudah mengetahui konsep acara yang akan dilaksanakan tanpa ada perintah ikut mengecat tembok dan menghias sekitaran rumahnya sesuai dengan konsep acara yang diadakan. Ada juga yang membantu panitia mengangkut barang-barang yang perlu dipersiapkan untuk kepentingan 
acara. Keamanan dan kebersihan pun dijaga bersama-sama oleh warga. Ketika acara diselenggarakan, banyak warga yang hadir untuk memperlihatkan hasil karya seni mereka dalam kegiatan pameran atau datang untuk mermaikan festival. Banyak juga warga yang menyediakan makanan untuk tamu atau wisatawan ketika acara seperti pameran, pementasan atau workshop kesenian diadakan. Warga yang tidak ikut berpartisipasi dalam pengkonsepan acara juga biasanya datang hadir untuk meramaikan acara festival yang diadakan tersebut. Kehadiran ini menunjukkan bahwa tersedianya waktu dari masyarakat untuk menghadiri pelaksanaan program telah disesuaikan sebelumnya di dalam rapat-rapat yang diadakan pengurus.

Partisipasi tenaga yang diberikan oleh warga RW 03 dalam pengembangan kampung kreatif juga dpat terlihat ketika kampung kreatif sedang membangun berbagai sarana dan prasarana untuk pengembangan aktivitas ekonomi warga seperti aula, kantin sanggar dan panggung yang lebih baik, banyak warga RW 03 yang bekerja sebagai kuli bangunan memberikan bantuan tenaga untuk membangun sarana tersebut di waktu luangnya tanpa meminta bayaran. Dari penggambaran tersebut dapat dilihat bagaiamana warga memberikan partisipasi tenaga untuk pengembangan kampung kreatif Dago Pojok. Adanya kerelaan warga memberikan tenaga dan waktunya untuk mendukung kegiatan pengembangan program dapat terjadi adanya keinginan dan kemampuan untuk membantu pengembangan program.

\section{c. Partisipasi Keahlian}

$\begin{array}{cr}\text { Dalam menjalanakan } & \text { program } \\ \text { pengembangan } & \text { masyarakat, }\end{array}$
keterlibatan masyarakat dalam memberikan keahliannya merupakan hal yang perlu diwujudkan untuk kelancaran program. Bukan hanya karena partisipasi keahlian dari masyarakat dapat membantu berjalannya program, tapi dengan menyumbangkan kehalian atau keterampilan untuk mendukung berjalannya program, masyarakat juga dapat berlatih memanfaatkan keahlian dan keterampilan yang mereka miliki sehingga potensi yang mereka miliki pun dapat terberdayakan. Seperti yang sudah dikatakan sebelumnya, Program kampung kreatif Dago Pojok memberikan kesempatan bagi masyarakat untuk memberikan kontribusi berupa keahlian atau keterampilan. Ada beberapa keahlian yang dapat disumbangkan oleh masyarakat untuk mendukung pengembangan kampung kreatif Dago Pojok, salah satu contoh partisipasi keahlian yang diberikan oleh warga adalah keahlian dan keterampilan dalam bidang kesenian. Keahlian warga dalam bidang kesenian merupakan hal yang menciptakan daya tarik wilayah RW 03 sebagai kampung wisata. Daya tarik utama yang membuat banyak orang datang ke Dago Pojok adalah aktivitas kesenian warga dimana wisatawan dapat menyaksikan pementasan kesenian, membeli hasil kerajinan tangan dan mengikuti pelatihan kesenian. Semua kegiatan tersebut membutuhkan keahlian dan keterampilan dari warga, di wilayah RW 03, sudah ada banyak warga yang memang memiliki keahlian di bidang kesenian atau berprofesi sebagai pengrajin, jadi ketika ada rombongan wisatawan datang untuk melihat pementasan atau mengikuti workshop, warga yang bisa berkesenian akan memberikan sumbangan keahlian untuk tampil dalam pementasan atau memberi pengarahan untuk wisatawan yang mengikuti workshop kesenian.

Di Kampung kreatif Dago Pojok, setiap bidang kesenian dibentuk sanggar keseniannya sendiri antara lain kesenian wayang, komunitas gondang, silat, teater, jaipong dan karinding. Masing-masing sanggar kesenian dikepalai oleh seorang warga Dago Pojok yang memiliki kemampuan dan bisa mengajar di bidang seni tersebut. Masing-masing sanggar kesenian memiliki jadwal latihan rutin untuk warga yang belum bisa berkesenian namun ingin belajar. Untuk warga RW 03, pelatihan tidak dikenakan biaya sementara untuk wisatawan yang datang dan ingin mengikuti workshop kesenian, akan ada tarif yang ditetapkan. Ketika ada pementasan, masingmasing bidang kesenian akan mempersiapkan 
diri untuk tampil di panggung pementasan dan apabila sedang diadakan workshop, warga yang memiliki keahlian seni akan memberikan pengarahan kepada wisatawan yang sedang mengikuti workshop. Para pengrajin di wilayah Dago Pojok seperti batik fraktal, alat musik bambu dan berbagai macam kerajinan tangan lainnya juga sering diminta untuk mengadakan workshop bagi wisatawan, warga yang memiliki kemampuan dalam bidang kerajinan tangan juga akan memberi pengarahan kepada wisatawan yang sedang mengikuti workshop. Selain seni kerajinan tangan dan seni pertunjukan, banyak juga warga Dago Pojok yang memiliki kemampuan di bidang seni rupa dan seni patung, bidang kesenian ini juga memiliki jadwal latihan khusus yang biasanya banyak diikuti oleh anak-anak untuk seni gambar dan pemuda untuk seni patung. Warga yang memiliki keahlian dalam bidang kesenian ini banya memberikan partisipasi keahlian ketika dalam mendekorasi atau menghias gang-gang ata tembok rumah dan jalan di sekitar wilayah RW 03 Dago Pojok. Sebagai kampung wisata yang menetapkan kesenian sebagai daya tarik wisatanya, penampilan fisik dari kampung Dago Pojok sudah seharusnya terlihat menarik, oleh karena itu tembok-tembok di sekitar RW 03 banyak yang dihiasi dengan lukisan-lukisan atau dibuatkan mural. Di beberapa jalan juga dipajang berbagai hasil kesenian seperti patung dan benda hasil kerajinan tangan. Semua dilakukan oleh warga setempat yang memiliki keahlian dibidang seni. Selain warga, wisatawan dari luar juga sering melukis dan membuat mural bersama warga untuk mendekorasi kampung Dago Pojok. Dari penggambaran tersebut, dapat dilihat bagaimana warga memberikan sumbangan keahliannya untuk pengembangan kampung wisata kreatif Dago Pojok. Kegiatan kesenian di Dago Pojok harus terus berjalan agar kampung kreatif sebagai kampung wisata berbasis masyarakat dapat terus berkembang dan ikut memajukan warga di wilayah RW 03 Dago Pojok. Kegiatan kesenian tersebut dapat terus berjalan karena adanya partisipasi keahlian yang diberikan oleh warga. Keahlian yang dimiliki warga juga dapat kita lihat disebarkan kepada warga yang belum memilikinya melalui pelatihan yang diadakan secara gratis untuk warga setempat. Warga yang tadinya tidak memiliki keterampilan bisa belajar dan mengembangkannya seperti contohnya ibu-ibu di RW 03 yang tidak memiliki pekerjaan mulai bisa membuat berbagai macam benda hasil kerajinan tangan yang memiliki nilai jual.

Bukan hanya keahlian dalam bidang kesenian, pengembangan kampung kreatif juga dapat berjalan dengan baik apabila ada sumbangan keahlian pada sektor yang lain seperti misalnya keahlian dalam pengorganisasian dan keahlian dala berdiplomasi dengan pihak lembaga atau instansi di luar Dago Pojok. Dalam beberapa event atau kegiatan yang dilaksanakan oleh kampung kreatif, bantuan dari pihak luar seperti misalnya untuk sponsor atau rekan media sangat dibutuhkan maka dari itu, warga yang menjadi pengurus acara harus mampu menjalin kerja sama dengan pihak luar dan dalam kampung kreatif sendiri terdapat struktur organisasi yang berperan untuk menjalankan program kampung kreatif dan pembentukan panitia ketika mengadakan acara. Untuk menjalankan hal tersebut diperlukan keahlian dalam bidang pengorganisasian dari warga sehingga pengembangan program dapt berjalan dengan baik melalui partisipasi keahlian yang diberikan oleh warga.

\section{d. Partisipasi Barang}

Jenis partisipasi selanjutnya yang dapat diberikan oleh masyarakat untuk pengembangan kampung wisata kreatif adalah partisipasi barang. Pada jenis partisipasi ini, masyarakat memberikan atau menyumbangkan barang kepemilikannya untuk mendukung pengembangan program. Dalam pengembangan kampung kreatif Dago Pojok, banyak warga juga memberikan partisipasi berupa barang kepemilikan baik barang yang bisa dipindahkan maupun tidak. Saat ini, kampung kreatif Dago Pojok sedang dalam proses pembangunan sarana dan 
fasilitas. Beberapa diantaranya adalah pembangunan aula, kantin, panggung dan ruang pertunjukan. Semua sarana tersebut dibangun di tanah yang dimiliki warga.

Warga yang memiliki tanah di Dago Pojok mengizinkan tanahnya untuk dibangunkan sarana dan fasilitas yang dapat mendukung program kampung kreatif tanpa pungutan biaya atau harga sewa ketimbang menjualnya kepada orang lain. Salah satu hal yang di himbau oleh penggagas untuk warga Dago Pojok adalah untuk tidak menjual tanah milik mereka kepada perusahaan pengembang properti untuk mencegah terjadinya pembangunan yang tidak menguntungkan masyarakat Dago Pojok. Karena itu, warga di sudah memiliki kesadaran untuk tidak menjual tanahnya dan memberikan tanahnya untuk keperluan program kampung kreatif. Untuk meningkatkan daya tarik fisik di kampung Dago Pojok, warga juga mengizinkan para seniman lokal untuk mengecat dan menggambar tembok rumah mereka sesuai dengan tema yang sedang diangkat agar wilayah perkampungan Dago Pojok jadi menarik untuk dilihat. Selain harta benda tak bergerak, warga juga banyak yang memberikan barang milik mereka untuk keperluan acara kampung kreatif seperti misalnya ketika di dalam acara akan mengadakan ngaliwet atau makan bersama, banyak warga yang meminjamkan perkakas untuk masaknya, contoh lainnya adalah warga yang memberikan barang-barang bekas atau perabotan rumah yang tidak terpakai banyak untuk dijadikan karya seni dalam acara festival atau pameran yang diadakan di kampung kreatif Dago Pojok. Dari penggambaran diatas, dapat dilihat bagaimana partisipasi barang dari masyarkat dapat membantu dan mendukung kegiatan yang diadakan program terutama program pembangunan yang tidak berdiri di bawah pemerintah atau lembaga manapun seperti kampung kreatif Dago Pojok. Partisipasi warga dengan memberikan harta atau barang kepemilikannya secara sukarela utuk mendukung program akan menjadi sesuatu yang mendorong program kampung kreatif.

\section{e. Partisipasi Uang}

Jenis partisipasi terakhir menurut Hamidjoyo adalah partisipasi dalam bentuk uang. Dalam pengembangan kampung wisata kreatif, uang diperlukan untuk biaya kegiatan seperti festival atau pameran yang diadakan setiap bulan dan untuk operasional dekorasi kampung. Hanya ada beberapa warga yang memberikan partisipasi uang kebanyakan merupakan pengurus dan tokoh masyarakat seperti keta RW. Mereka menggunakan uangnya untuk mendukung kegiatan-kegiatan yang ada di kampung kreatif seperti misalnya dalam pembuatan sanggar gondang, ada beberapa warga yang dengan sukarela membelikan uangnya untuk dibelikan peralatan gondang. Kampung kreatif Dago Pojok mempersilakan siapapun warga yang ingin memberikan sumbangan berupa uang untuk kegiatan-kegiatan kampung kreatif, namun karena kebanyakan warga RW 03 adalah masyarakat dengan tingkat ekonomi menengah kebawah, tidak banyak yang bisa memberikan sumbangan berupa uang dalam jumlah yang cukup banyak dan tidak semua warga ikut dalam kegiatan kesenian di kampung kreatif sehingga pengurus merasa tidak bisa memungut iuran dari warga. Karena itulah rencananya iuran akan dijalankan pada setiap komunitas atau sanggar kesenian namun pengurus masih merasa perlu adanya konsistensi dari sanggar-sanggar kesenian di RW 03 dalam mendapatkan penghasilan melalui aktivitas kesenian dan kreasi mereka supaya iuran bisa ditetapkan dan setiap komunitas seni dapat menjalankan iuran yang telah ditetapkan dengan baik. Partisipasi uang biasanya diberikan oleh warga yang ada di kepengurusan seperti misalnya ketua dan wakil ketua kampung kreatif yang memang secara pribadi sudah mampu menghasilkan uang dalam jumlah yang cukup banyak dari berkesenian. Partisipasi mereka dalam bentuk uang dapat terlihat pada saat ada warga yang ingin memulai usaha kreatif namun kas kampung kreatif tidak cukup untuk memberikan bantuan modal disaat seperti itu, ketua dan wakil kampung kreatif 
menggunakan uang pribadi mereka untuk mendukung kegiatan warga tersebut.

Dari penggambaran tersebut dapat dilihat bahwa belum semua warga dapat memberikan partisipasi dalam bentuk uang karena belum adanya aturan atau sistem yang menjadi wadah warga untuk memberikan partisipasinya dalam bentuk uang. Dengan kata lain, kesempatan warga untuk memberikan partisipasi berupa uang belum tersedia dengan baik dan kemampuan untuk memberikan partisipasi dalam bentuk uang belum dimiliki oleh seluruh warga. Karena itu sampai hari ini, uang yang dibutuhkan untuk pengembangan kampung kreatif Dago Pojok kebanyakan masih berasal dari hasil kerjasama dengan sponsor atau mendapat bantuan dari pihak lain seperti pemerintah daerah atau lembaga-lembaga lain.

\section{Pembahasan Penelitian \\ 1. Prasyarat Partisipasi}

Berdasarkan hasil penelitian yang telah dipaparkan sebelumnya, pada bagian ini akan dibahas bagaimana hasil-hasil penelitian yang telah didapatkan kesesuaiannya dengan konsep prasyarat partisipasi oleh Carry (1970:145) yang mencakup aspek mengenai adanya kesempatan untuk berpartisipasi, adanya kemampuan dan adanya keinginan baik dari masyarakat itu sendiri maupun dari apa yang telah diberikan program. Terpenuhinya prasyarat partisipasi pada warga kemudian akan memunculkan partisipasi yang telah diberikan warga dalam berbagai jenis. Bagaimana prasyarat-prasyarat partisipasi tersebut terpenuhi atau tidak selengkapnya akan dibahas pada sub-bab ini.

a. Kesempatan Masyarakat

Kesempatan yang tersedia untuk berpartisipasi bagi warga RW 03, sebagaimana yang telah diungkapkan pada hasil penelitian, sangat luas. Kesempatan masyarakat untuk berpartisipasi dilihat dari adanya waktu yang dimiliki masyarakat untuk terlibat, adanya situasi yang mengundang partisipasi warga dan adanya kebebasan berpartisipasi pada masyarakat. Carry dalam Iskandar (1993:77) mengungkapkan bahwa dalam memberikan kesempatan berpartisipasi masyarakat perlu diberikan ruang untuk bebas memilih dan menjadikan mereka mandiri. Kondisi tersebut sesuai dengan apa yang terjadi pada warga RW 03 dalam pengembangan kampung kreatif. Seperti yang telah diungkapkan dalam hasil penelitian, masyarakat tidak hanya dilibatkan dalam pelaksanaan program saja, namun sebelum program dijalankan, masyarakat telah diajak berdiskusi dan diberikan sosialisasi mengenai program, sehingga dengan begitu masyarakat memiliki kesempatan dan kebebasan dalam mengarahkan program agar sesuai dengan kebutuhan mereka dan menentukan keterlibatannya di dalamnya. Sebagaimana yang diungkapkan Ismawan (2003:20) yang mengungkapkan pentingnya kebebasan masyarakat sebagai berikut:

"Kebebasan akan memupuk masyarakat untuk mandiri dalam mengelola kegiatan yang mereka inginkan. Kemudian hal itu akan mengakibatkan terjadinya proses pemberdayaan yang akan melahirkan kemampuan masyarakat untuk memperbaiki keadaan lingkungannya mencapai kesejahteraan."

Dengan adanya kebebasan tersebut, maka masyarakat dipupuk untuk dapat memahami permasalahan di dalam lingkungannya sendiri sehingga hal-hal yang dilakukan sesuai dengan apa yang sudah mereka tentukan dengan mempertimbangkan hal-hal yang mereka butuhkan dalam suatu program pembangunan.

Kesempatan dalam berpartisipasi yang tersedia untuk warga RW 03 cukup luas, sebagaimana yang telah diungkapkan dalam hasil penelitian, dalam mengembangkan daya tarik wisatanya, kampung kreatif melibatkan hasil dan aktivitas kesenian dari warga, selain itu warga juga diberikan kebebasan dan kesempatan untuk menyampaikan saran dan pendapatnya melalui rapat yang diadakan secara terbuka. Soetarso dalam Iskandar (1993: 77-78) menyebutkan bahwa salah satu orientasi nilai yang ada pada prasyarat partisipasi masyarakat yang merupakan landasan berpartisipasi adalah dengan mengakui akan arti pentingnya penggunaan 
diskusi, pertemuan dan konsultasi-konsultasi sebagai metode yang digunakan untuk menanggulangi berbagai masalah individu maupun sosial. Sesuai dengan konsep tersebut, kampung kreatif Dago pojok telah memberikan kesempatan bagi masyarakat untuk berdiskusi mengenai pengembangan program dari dari sebelum program dilaksanakan sampai saat ini berjalan. Adanya diskusi dengan warga menunjukkan bahwa adanya kesempatan bagi masyarakat untuk memberi partisipasi pemikiran seperti masukan, saran maupun kritikan. Selain itu, konsep pengembangan pariwisata kreatif berbasis masyarakat menuntut keterlibatan masyarakat untuk dapat berjalan dengan baik. b. Kemampuan masyarakat

Salah satu aspek lain yang menjadi prasyarat untuk terciptanya partisipasi dari masyarakat adalah adanya kemampuan masyarakat untuk ikut serta dalam pengelolaan program dan kegiatan yang dilaksanakannya. Sebagaimana yang telah diungkapkan pada hasil penelitian, konsep dari program kampung kreatif yang bertujuan untuk menjadikan wilayah RW 03 Dago Pojok sebagai destinasi pariwisata berbasis masyarakat didasari dari potensi yang ada di masyarakat. Banyak warga yang memiliki kemampuan dibidang kesenian dan kerajinan tangan sehingga apabila wilayah RW 03 dijadikan kampung wisata dengan daya tarik berupa kesenian, warga dapat berpartisipasi dengan baik karena program pembangunan yang dilaksanakan sesuai dengan kemampuan dan kebiasaan masyarakat. Warga juga ikut berpartisipasi dalam pengembangan daya tarik wisata melalui pementasan dan pelatihan serta pameran hasil seni kerajinan tangan. Dengan banyaknya aktivitas kesenian dari warga, wisatawan yang memiliki minat pada bidang kesenian dan berbagai komunitas seni pun tertarik untuk berkunjung untuk belajar maupun berkesenian bersama dengan warga. Pelatihan kesenian dan kerajinan tangan juga sering ditujukan untuk warga yang belum memiliki kemampuan di bidang kesenian tanpa pungutan biaya. Semua itu dapat terwujud dengan baik karena adanya keterlibatan masyarakat yang memiliki kemampuan di bidang kesenian untuk menampilkan kemampuannya pada dalam acara pementasan dan juga membagikan kemampuannya di bidang kesenian kepada warga maupun wisatawan. Pengelolaan kampung kreatif Dago Pojok pun sepenuhnya diserahkan kepada warga setempat. Hal ini menunjukkan bahwa warga RW 03 dipercaya memiliki kemampuan untuk bekerja sama dalam mengelola program dengan masing-masing peran kerjanya sehingga kepengurusan program dapat sepenuhnya diisi oleh warga setempat. Penempatan warga dalam kepengurusan juga dapat mengembangkan kemampuan warga karena semakin terbiasa mengelola jalannya program dan bersamasama merencanakan langkah-langkah untuk kemajuan program dan wilayah mereka

Terkait dengan kemampuan, Robbin (2007:57) mengungkapkan bahwa kemampuan berarti kapasitas seseorang individu unutk melakukan beragam tugas dalam suatu pekerjaan. Kemampuan (Ability) adalah kecakapan atau potensi seseorang individu untuk menguasai keahlian dalam melakukan atau mengerrjakan beragam tugas dalam suatu pekerjaan atau suatu penilaian. Lebih lanjut lagi, Robbin membagi dua jenis kemampuan antara lain:

1. Kemampuan intelektual (intelectual ability) yaitu kemampuan yang dibutuhkan untuk melakukan berbagai aktivitas mental-berfikir, menalar dan memecahkan masalah.

2. Kemampuan fisik (physical ability) yaitu kemampuan melakukan tugas-tugas yang menuntut stamina, keterampilan, kekuatan, dan karakteristik serupa.

Dari konsep tersebut dapat dipahami bahwa kemampuan partisipasi adalah segala sesuatu yang berkaitan dengan aspek-aspek kemampuan masyarakat seperti kekuatan, keterampilan dan aktivitas berpikir untuk mendukung pengembangan kampung kreatif Dago Pojok. Dalam suatu program pengembangan masyarakat, perlu dipastikan adanya kemampuan pada masyarakat sehingga masyarakat dapat terdorong untuk ikut serta membantu program. Dengan adanya 
kemampuan-kemampuan tersebut, masyarakat dapat melakukan hal-hal yang diperlukan untuk kemajuan program sehingga melalui kemampuan tersebut, masyarakat dapat ikut terlibat dalam mendorong kemajuan program. Kemampuan untuk memberikan partisipasi pada warga RW 03 Dago Pojok dapat dikatakan sejalan dengan konsep tersebut. Dengan adanya kemampuan warga pada berbagai aspek seperti kemampuan fisik, mental maupun materi, warga dapat memberikan partisipasi yang sejalan dengan yang kemampuan yang mereka miliki. Partisipasi dalam bentuk tenaga dapat muncul karena ada kemampuan fisik dari warga yang memungkinkan mereka untuk menggunakan tenaga mereka dalam berpartisipasi. Partisipasi warga dalam memberikan pemikiran melalui diskusi untuk pengembangan program juga dapat terjadi karena adanya kemampuan warga secara mental untuk memberikan partisipasinya. Kemampuan materi dari warga juga merupakan aspek yang mendasari adanya partisipasi barang dan uang dari warga untuk mendukung program. Dari penggambaran tersebut dapat dilihat bagaimana dengan adanya kemampuan dari masyarakat, partisipasi warga untuk mendukung pengembangan program pun dapat terwujud dan terdorong karena setiap aktivitas atau kegiatan yang perlu dilakukan untuk mendukung program dapat dilakukan oleh warga.

c. Keinginan Masyarakat

Satu lagi Prasyarat partisipasi yang diungkapkan oleh Carry adalah keinginan atau Kemauan masyarakat. Adanya keinginan atau kemauan adalah hal yang sangat penting untuk diwijudkan untuk mendorong adanya partisipasi masyarakat dalam suatu program. Tanpa adanya keinginan dari masyarakat, kesempatan untuk berpartisipasi yang disediakan tidak akan mendapatkan respon berupa partisipasi nyata, dan kemampuan yang dimiliki masyarakat pun enggan mereka gunakan untuk mendukung kegiatan-kegiatan program. Seperti yang sudah diungkapkan dalam hasil penelitian, keinginan warga RW 03 untuk berpartisipasi dapat terlihat dari intensitas warga dalam mengikuti kegiatankegiatan yang berkaitan dengan program kampung kreatif. Kemauan untuk ikut menjalankan program tersebut muncul karena masyarakat merasa dilibatkan dalam program dan masyarakat menginginkan adanya perubahan yang lebih baik untuk kampung mereka. Melihat dari hasil penelitian, dapat dikatakan bahwa kemauan warga untuk ikut serta tergolong tinggi. Meskipun tidak semua warga memiliki kemauan yang tinggi untuk banyak berkorban waktu, tenaga dan materi, namun ada beberapa warga yang memiliki kemauan tinggi sehingga dedikasi atau keterlibatannya memberikan dampak yang besar untuk kemajuan program. Hal tersebut dapat dilihat dari bagaimana beberapa warga rela menyumbangkan sejumlah uangnya untuk fasilitas dan keperluan pementasan seni, atau menyediakan waktunya untuk menjadi instruktur ketika mengadakan pelatihan seni untuk wisatawan maupun warga, selain itu saran dan masukan yang diberikan warga melalui rapat yang mereka hadiri juga menunjukkan adanya kepedulian dan keinginan mereka untuk terlibat dan ikut memikirkan tentang keberlangsungan program.

Kemauan juga dapat dikatakan sebagai kemampuan untuk membuat pilihan-pilihan bebas, memutuskan, melatih mengendalikan diri, serta bertindak (Lindzey, 1993). Dalam konteks partisipasi, dapat dikatakan bahwa kemauan juga berkaitan dengan pilihan warga untuk menentukan keterlibatan mereka dalam suatu program. Dalam pengembangan kampung kreatif, warga memilih untuk terlibat, adanya kesempatan dan kebebasan bagi warga untuk berpartisipasi juga akan mendorong keinginan warga karena masyarakat dapat menentukan bagaimana mereka dapat berpartisipasi.

\section{Jenis Partisipasi}

Terpenuhinya prasyarat partisipasi dapat memunculkan partisipasi dari masyarakat. Pada program kampung wisata kreatif Dago Pojok, partisipasi masyarakat telah berjalan dengan terpenuhinya prasyaratprasyarat partisipasi yang telah dibahas pada 
sub-bab sebelumnya. Pada sub-bab ini, hasil penelitian mengenai jenis-jeni partisipasi yang telah diberikan masyarakat akan dibahas apakah sejalan dengan konsep jenis partisipasi oleh Hamidjoyo yang mencakup partisipasi pemikiran, tenaga, keahlian, barang dan uang. a. Partisipasi Pemikiran

Partisipasi pemikiran merupakan jenis partisipasi yang diberikan masyarakat dengan bentuk memberikan pendapat yang konstruktif, gagasan, masukan, dan kritik dalam proses pengembangan kampung kreatif Dago Pojok. Dengan adanya masukan, kritik dan gagasan datri masyarakat, program pengembangan masyarakat dapat berjalan dengan baik karena usulan dan gagasan dari masyarakat dapat mengarahkan program menjadi lebih tepat sasaran dengan kebutuhan dan keinginan masyarakat. Menurut Hamijoyo (2007:21) Partisipasi pemikiran adalah partisipasi berupa sumbangan berupa ide, pendapat atau buah pikiran konstruktif, baik untuk menyusun program maupun untuk memperlancar pelaksanaan program dan juga untuk mewujudkannya dengan memberikan pengalaman dan pengetahuan guna mengembangkan kegiatan yang diikutinya. Melihat dari hasil penelitian yang dilihat berdasarkan dari hasil wawancara mendalam dan observasi, Partisipasi pemikiran yang diberikan warga Dago Pojok sejalan dengan konsep yang diungkapkan Hamidjoyo. Partisipasi berupa sumbangan ide, pendapat atau buah pemikiran yang membangun dan saran, telah dilaksanakan masyarakat pada saat perencanaan kegiatan yang dilakukan dalam bentuk rapat dan diskusi. Partisipasi pemikiran tersebut sudah dilakukan sejak tahap perencanaan program, sebelum program kampung kreatif berjalan, konsep tersebut didiskusikan dan di rapatkan terlebih dahulu dengan masyarakat. Setelah program berjalan, setiap sebulan sekali diadakan rapat untuk mengevaluasi program dimana warga boleh datang untuk memberikan partisipasi pemikiran mereka. Wujud partisipasi pemikiran yang telah digambarkan pada hasil penelitian menunjukkan bahwa partisipasi pemikiran merupakan sesuatu yang dapat mendukung kelancaran program untuk mencapai tujuannya dan dalam pengembangan kampung wisata kreatif, partisipasi masyarakat RW 03 dalam memberikan sumbangan pemikiran berjalan dengan baik sebagaimana warga RW 03 memberikan sumbangan ide, pendapat dan buah pemikirannya melalui wadah yang disediakan seperti rapat dan diskusi yang tujuannya adalah untuk kelancaran pengembangan program. Pengalaman dan pengetahuan warga juga dibagikan kepada warga lain melalui berbagai kegiatan yang ada di RW 03 seperti misalnya pelatihan kesenian dan diskusi bersama membahas agenda yang berkaitan dengan pengembangan kampung kreatif. Terkait dengan partisipasi pemikiran, Carry (1970) mengatakan :

"Two other important aspects of participation may include what members do between meetings and what part they play during meetings. The between meetings participations may include a variety of tasks from typing minutes to planning strategy. Participation during meetings indicates the individual's role in the decision-making process of the organiszations"

Pernyataan Carry menggambarkan bahwa jenis partisipasi pikiran adalah dengan hadir dalam rapat, dan secara mendalam lagi adalah apa yang dilakukan ketika rapat berlangsung. Mengacu dari konsep tersebut, kehadiran warga RW 03 dalam rapat dan diskusi memiliki peran untuk membuat keputusan tentang kegiatan yang akan diadakan untuk pengembangan kampung wisata kreatif. Dengan adanya partisipasi warga dalam hal tersebut, maka warga dapat dikatakan memiliki peran yang dapat menentukan keputusan dalam pengembangan program. Dari penggambaran tersebut dapat dikatakan bahwa partisipasi pemikiran oleh warga RW 03 merupakan sesuatu yang telah terwujud karena terbukanya kesempatan untuk berpartisipasi memberikan sumbangan pemikiran yang disertai juga dengan adanya kemampuan warga dalam memberikan pendapat, gagasan atau ide. Diikuti juga 
dengan adanya keinginan warga untuk terlibat membantu program kampung wisata kreatif agar dapat lebih maju.

\section{b. Partisipasi Tenaga}

Partisipasi tenaga merupakan partisipasi yang ditunjukan masyarakat melalui kehadirannya pada saat pelaksanaan kegiatan di kampung kreatif Dago Pojok. Menurut Hamijoyo (2007:21), partisipasi tenaga adalah partisipasi yang diberikan dalam bentuk tenaga untuk pelaksanaan usaha-usaha yang dapat menunjang keberhasilan suatu program. Partisipasi tenaga dapat dilihat dari kehadiran masyarakat pada saat pelaksanaan program. Kehadiran ini menunjukkan bahwa tersedianya waktu dari masyarakat untuk menghadiri pelaksanaan program yang telah disesuaikan sebelumnya di dalam rapat. Kegiatan yang menunjang perkembangan program kampung kreatif seperti mengadakan festival dan workshop untuk wisatawan, memerlukan keterlibatan penuh dari masyarakat setempat. Bukan hanya kehadiran ketika kegiatan dilaksanakan, namun juga ketiga kegiatan tersebut dipersiapkan. Sebagaimana yang telah dijelaskan pada hasil penelitian, persiapan festival dan acara-acara yang diadakan oleh kampung kreatif dilaksanakan dengan bergotong royong sehingga dalam mempersiapkan seluruh aspek yang diperlukan agar acara dapat berjalan dengan baik, bantuan dari segenap masyarakat amat dibutuhkan.

Partisipasi tenaga yang ditunjukan oleh warga RW 03 dalam mendukung pengembangan kampung kreatif Dago Pojok, sejalan dengan apa yang diungkapkan oleh Hamidjoyo. Masyarakat memberikan sumbangan-sumbangan tenaganya untuk menunjang keberhasilan program kampung kreatif Dago Pojok. Usaha-usaha yang ditunjukkan warga RW 03 dapat dilihat dari bagaimana persiapan acara di kampung kreatif dilaksanakan dengan bergotong royong dan kepanitaannya juga diisi oleh warga setempat. Ketika acara diselenggarakan, warga juga banyak yang datang untuk memperlihatkan hasil karya seni mereka dalam acara pameran atau sekedar meramaikan ketika mengadakan festival. Dengan begitu dapat dilihat bagaimana warga menyumbangkan tenaga dan waktunya untuk ikut mendukung kemajuan program kampung wisata kreatif di wilayah RW 03 Dago Pojok dan seluruh keterlibatan dari warga didasari oleh keinginan sendiri dan bukan karena ada paksaan.

c. Partisipasi Keahlian

Dalam menjalanakan program pengembangan masyarakat, adanya keahlian merupakan hal yang perlu diwujudkan untuk kelancaran program. Partisipasi keahlian dari masyarakat dapat membantu berjalannya dan dengan menyumbangkan keahlian atau keterampilan untuk mendukung berjalannya program, masyarakat juga dapat berlatih memanfaatkan keahlian dan keterampilan yang mereka miliki sehingga potensi yang mereka miliki pun dapat terberdayakan. Partisipasi keahlian merupakan hal yang diperlukan dalam pengembangan kampung kreatif. Sebagai kampung wisata, perlu ada partisipasi keahlian yang diberikan dari masyarakat karena daya tarik wisata dari kampung kreatif Dago Pojok adalah pada kesenian. Sumbangan keahlian khususnya pada bidang kesenian, dapat menjadi peluang yang mengundang wisatawan datang untuk belajar atau menikmati kesenian dan juga untuk menyebarkan keahlian tersebut kepada warga lain yang belum memilikinya. Keahlian dibidang kesenian tersebut juga dapat dimanfaatkan warga untuk membuat kerajinan tangan yang memiliki nilai ekonomi. Terkait partisipasi keahlian, Hamijoyo (2007:21) mengungkapkan:

"Partisipasi keterampilan, yaitu memberikan dorongan melalui keterampilan yang dimilikinya kepada anggota masyarakat lain yang membutuhkannya. Dengan maksud agar orang tersebut dapat melakukan kegiatan yang dapat meningkatkan kesejahteraan sosialnya”.

Pernyataan tersebut sesuai dengan apa yang terjadi pada masyarakat RW 03 Dago Pojok. Warga yang memiliki keahlian dibidang kesenian dan kerajinan tangan tidak hanya menggunakan keahlian yang dimilikinya untuk acara-acara yang ada di 
kampung kreatif, tapi juga untuk melakukan pelatihan kepada warga lain agar mereka bisa berkesenian dan mencari peluang untuk mencari uang dari bidang kesenian dan kerajinan tangan. Pengembangan kampung kreatif Dago Pojok sebagai salah satu bentuk dari pariwisata kreatif yang berbasis masyarakat tentu membutuhkan keterlibatan keahlian dari masyarakat. Sebagimana menurut Raymond (2007), Pariwisata kreatif adalah sebuah pengalaman berwisata yang memberikan peluang kepada wisatawan untuk mengembangkan potensi kreatifnya dengan karakteristik sebagai berikut:

1. Tema berhubungan dengan budaya lokal yang mencakup antara lain aktivitas budaya masyarakat, makanan, alam, kesenian.

2. Bersifat informal/tidak kaku dan fleksibel

3. Bersifat hand on yang melibatkan pengunjung untuk belajar secara interaktif

4. Peserta dibatasi pada kelompok kecil atau personal

5. Kegiatan dilakukan di tempat pengajar atau tempat kerja/bengkel, bukan di ruang seminar mewah. Hal ini untuk mendukung suasana ontentik dan informal

6. Memperbolehkan pengunjung mengeksplorasi kreativitas mereka sehingga kurikulum pengajaran tidak dibatasi secara ketat/fleksibel.

7. Mendukung pariwisata berkelanjutan dengan adanya pasar market bagi peningkatan kemampuan/skill tradisional suatu komunitas, serta dapat memanfaatkan prasarana dan sarana yang sudah ada.

8. Mendekatkan diri pada komunitas lokal, termasuk pengajar/ instruktur dan masyarakat di sekitarnya.

Dari konsep tersebut dapat dilihat bagaimana pentingnya keahlian masyarakat dibidang kesenian untuk mengembangkan daya tarik wisata dan menyebarkan keahlian tersebut kepada warga lain. Hal ini sejalan dengan yang terjadi di RW 03 Dago Pojok, dimana warga yang sudah memiliki kemampuan dibidang kesenian dan kerajinan tangan sering mengadakan workshop untuk penduduk lokal yang mau belajar dan mereka yang sudah memiliki kemampuan seni, hasil karyanya dapat ditampilkan dan menarik para pengunjung sehingga kampung kreatif Dago Pojok pun semakin mengundang minat wisatawan yang ingin berlibur sambil menikmati dan mempelajari kesenian baik kesenian kontemporer maupun tradisional yang ada di kampung kreatif Dago Pojok. Melihat hal tersebut, juga dari pemaparan lebih terperinci pada bagian hasil penelitian mengenai bagaimana partisipasi keahlian oleh warga RW 03 Dago Pojok, dapat dilihat bahwa partisipasi keahlian dalam pengembangan kampung kreatif Dago Pojok memang diwujudkan untuk memberi dukungan kepada kemajuan program dan juga peningkatan kemampuan kepada warga.

d. Partisipasi Barang

Jenis partisipasi selanjutnya yang akan dibahas dalam pengembangan kampung kreatif Dago Pojok adalah partisipasi barang. Menurut Hamijoyo (2007:21), partisipasi barang merupakan jenis partisipasi masyarakat yang diberikan dalam bentuk barang yang mencakup peralatan dan perlengkapan yang dibutuhkan. Barang yang dimaksudkan dalam hal ini adalah barang-barang yang dimiliki oleh anggota yang secara sukarela digunakan untuk keperluan kegiatan atau acara dari program kampung kreatif.

Partisipasi barang adalah partisipasi dalam bentuk menyumbang barang atau harta benda, biasanya berupa alat-alat kerja atau perkakas. Sumbangan harta benda kepemilikan warga seperti tanah atau rumah juga termasuk kedalam partisipasi barang. Partisipasi ini dilakukan dengan cara menyumbangkan barang pribadi yang digunakan untuk kegiatan pengembangan kampung wisata kreatif. Tidak ada ketentuan berapa jumlah sumbangan yang harus diberikan oleh masing-masing individu. Jumlah barang yang disumbangkan disesuaikan dengan kemampuan dari masingmasing individu. Untuk mendukung program kampung wisata kreatif, beberapa yang memiliki tanah menyumbangkan tanah miliknya untuk dibangunkan sarana dan prasarana yang mendukung program kampung wisata kreatif seperti panggung, sanggar dan 
ruang pertunjukan. Sumbangan tersebut sangat membantu program untuk menekan biaya pembangunan sarana dan prasarana karena tidak perlu membeli atau menyewakan tanah lagi. Untuk membuat wilayah RW 03 terlihat lebih menarik, warga juga secara sukarela mengizinkan tembok rumahnya untuk dibuatkan mural atau di tempelkan lukisan dan hasil kesenian warga. Sebagai kampung wisata dengan kesenian sebagai daya tarik wisatanya, kondisi fisik perkampungan yang menarik adalah salah satu aspek yang akan mendukung ketertarikan wisatawan untuk datang, oleh karena itu di wilayah RW 03 tembok-tembok gang dan rumah warga selalu dibuat menarik dengan gambar-gambar dan pajangan karya seni yang secara berkala berganti sesuai dengan tema yang sedang diangkat. Tanpa adanya keralaan warga dalam memberikanizin pada rumah atau bangunan miliknya untuk digambar, maka hal tersebut akan sulit untuk terwujud. Festival dan workshop seni yang diadakan juga mendapat banyak dukungan partisipasi barang dari warga seperti perkakas yang diperlukan untuk menggelar pentas seni hampir seluruhnya adalah milik warga yang diberikan kepada pengurus untuk dipergunakan setiap ada acara atau festival.

Adanya partisipasi dalam bentuk barang yang diberikan telah menunjukan bahwa tingginya kepedulian warga terhadap perkembangan program kampung wisata kreatif. Karena mereka menyadari bahwa ada manfaat positif yang dapat mereka peroleh dari program sehingga keinginan mereka untuk terus mendukung program pun semakin tinggi. Partisipasi barang secara menekan biaya yang sebenarnya bisa di gunakan untuk membeli barang-barang tersebut dan sebagaimana kampung kreatif merupakan program yang saat ini tidak didanai oleh pemerintah lembaga manapun, bantuan warga dalam bentuk barang merupakan hal yang dapat mendukung kemajuan program kampung wisata kreatif.

e. Partisipasi Uang

Partisipasi uang adalah bentuk partisipasi untuk memperlancar usaha-usaha bagi pencapaian kebutuhan masyarakat yang memperlukan bantuan. partisipasi ini menggunakan uang sebagai alat guna mencapai sesuatu yang diinginkan biasanya tingkat partisipasi tersebut dilakukan oleh orang-orang pada kalangan atas (Hamijoyo, 2007:21). Dalam pengembangan kampung kreatif Dago Pojok, partisipasi uang hanya dilakukan oleh beberapa orang di RW 03 dalam situasi tertentu seperti yang telah dijelaskan dalamhasil penelitian. Masyarakat tidak semuanya memberikan partisipasi berupa uang. Hal ini dikarenakan belum adanya kewajiban untuk memberikan iuran dan sistem untuk mengelola dari pengurus. Dengan kata lain, belum ada kesempatan yang memadai untuk mewujudkan partisipasi uang dari masyarakat secara menyeluruh. Alasan mengapa pengurus belum memberlakukan iuran rutin yang akan memberikan kesempatan bagi warga untuk memberikan keterlibatan berupa uang, adalah karena pengurus belum merasa yakin dengan kemampuan warga dalam memberikan iuran secara rutin. Pengurus merasa, keuntungan materi yang didapat warga dari hasil karya seninya di kampung kreatif belum konsisten. Sehingga diberlakukannya iuran rutin dianggap akan memberatkan warga. Meskipun belum adanya regulasi yang mengatur partisipasi uang seperti iuran, dalam beberapa kasus, banyak warga yang bersedia mengumpulkan uang seadanya untuk keperluan program. Hal ini menunjukkan bahwa sudah ada keinginan warga untuk memberikan partisipasinya dalam bentuk uang, meskipun tidak semua warga memberikan partisipasi uang dalam jumlah yang sama dan dalam waktu yang rutin. Partisipasi uang yang diberikan oleh warga sejauh ini dalam pengembangan kampung kreatif Dago Pojok bukan hanya membantu program mengadakan kegiatan namun juga untuk membantu warga yang membutuhkan modal uang untuk memulai usaha kecil dari hasil kerjinan tangan maupun kuliner. Adanya partisipasi uang dari sebagian warga yang memiliki kemampuan lebih untuk memberikan partisipasi berupa uang sejauh ini menjadi sesuatu yang mendukung pengembangan program. 


\section{Kesimpulan}

Berdasarkan dari penggambaran hasil penelitian dan pembahasan pada bab sebelumnya, pada bab ini akan ditarik kesimpulan mengenai bagaimana partisipasi masyarakat dalam pengembangan kampung wisata kreatif Dago pojok dilihat dari prasyarat dan jenis partisipasi. Dalam pelaksanaan program kampung kreatif Dago Pojok, prasyarat yang menciptakan situasi untuk berpartisipasi telah tersedia dan partisipasi masyarakat dalam berbagai jenis juga telah berjalan untuk mendukung keberhasilan dan kelancaran program.

\section{Prasyarat Partisipasi}

Pada Program Kampung Kreatif Dago Pojok, prasyarat partisipasi yang meliputi kesempatan, kemampuan dan keinginan telah tersedia sehingga dengan terciptanya situasi yang sejalan dengan prasyarat tersebut, keterlibatan dari masyarakat untuk mendukung program supaya berjalan dengan baik akan terwujud sehingga dapat kemudian dilihat bagaimana jenis partisipasi yang diberikan oleh masyarakat. Adanya kesempatan masyarakat untuk berpartisipasi dapat dillihat dari adanya waktu yang dimiliki oleh masyarakat untuk ikut serta dalam kegiatankegiatan pengembangan program. Kebanyakan dari warga memiliki lebih banyak kesempatan untuk berpartisipasi pada hari libur atau setelah jam kerja karena pada saat itulah mereka memiliki waktu luang dan tidak sedang disibukkan dengan urusan pekerjaan. Beberapa warga yang bekerja dirumah dan pemuda yang masih bersekolah atau belum memiliki pekerjaan, memiliki kesempatan waktu yang lebih besar untuk mengikuti kegiatan-kegiatan yang berhubungan dengan kampung kreatif sehingga mereka dapat hadir membantu aktivitas-aktivitas pengembangan kampung kreatif saat warga yang lain sedang memiliki kesibukannya sendiri dengan pekerjaan dan tidak bisa ikut berpartisipasi.

Kemampuan masyrakat dalam berpartisipasi dapat dilihat dari kemampuan fisik, mental dan materi yang dimiliki oleh warga untuk dapat membantu kegiatan pengembangan kampung kreatif. Kemampuan fisik merupakan kemampuan yang melibatkan keahlian, tenaga dan keterampilan. Adanya kemampuan fisik pada warga RW 03 dapat dilihat dari banyaknya warga RW 03 yang masih termasuk kedalam usia kerja atau usia produktif dan mayoritas dari warga memiliki kondisi badan yang sehat serta tidak cacat sehingga tenaga mereka dapat dipergunakan untuk mendukung kegiatan-kegiatan di kampung kreatif. Kemampuan mental merupakan kemampuan yang meliputi pemberian kemampuan berpikir, pemberian ide, pendapat dan juga sikap serta perilaku warga. Adanya kemampuan mental warga RW 03 dapat dilihat dari kenyataan bahwa banyak warga yang memiliki tingkat pendidikan sampai SMA keatas selain itu warga juga banyak yang sudah bekerja atau setidaknya pernah memiliki pekerjaan atau mengikuti kegiatan yang membutuhkan kemampuan untuk berpikir dan berinteraksi dengan baik. Kemampuan masyarakat juga dilihat dari adanya kemampuan materi warga untuk mengikuti kegiatan kampung kreatif. Kemampuan materi warga dapat dilihat dari tingkat ekonomi nya. Mayoritas warga RW 03 berada pada tingkat ekonomi menengah kebawah, namun masih ada beberapa warga yang termasuk kedalam tingkat ekonomi menengah keatas dan juga ada beberapa warga yang memiliki aset di wilayah Dago Pojok seperti tanah, rumah atau kendaraan.

Keinginan masyarakat untuk berpartisipasi dapat terwujud dari adanya motivasi dari dalam individu warga maupun dari luar. Motivasi dari dalam individu warga yang mendorong mereka untuk ikut berpartisipasi adalah adanya keinginan mereka untuk memberikan sebuah perubahan sosial yang lebih baik untuk wilayah Dago Pojok serta keinginan agar mereka dapat mencari uang melalui kegiatan kreatifnya di daerah mereka sendiri. Selain motivasi dari dalam diri mereka sendiri, keinginan warga juga muncul karena adanya dorongan dari luar seperti misalnya dari program. 


\section{Jenis Partisipasi}

Dengan terpenuhinya prasyarat partisipasi di kampung wisata kreatif Dago Pojok, warga dapat memberikan berbagai jenis partisipasi untuk mendukung pengembangan kampung kreatif Dago Pojok. Jenis partisipasi yang dilihat dalam penlitian ini adalah partisipasi pemikiran, tenaga, keahlian, barang dan uang. Partisipasi pemikiran oleh Warga RW 03 dapat terlihat dari bagaimana warga memberikan ide atau gagasan mengenai kegiatan yang akan dilaksanakan serta langkah pengembangan program selanjutnya dalam rapat atau diskusi informal yang diselenggarakan.

Partisipasi Tenaga merupakan salah satu jenis partisipasi yang terlihat paling dominan dilakukan oleh warga. Sebagaimana dalam melaksanakan persiapan kegiatan atau membangun sarana prasarana untuk mendukung kegiatan kampung kreatif, hampir seluruh warga menyumbangkan tenaga untuk bersama-sama gotong royong membangun dan mempersiapkan apa yang dibutuhkan untuk kegiatan program. Partisipasi keahlian warga RW 03 dalam mendukung pengembangan program kampung kreatif dapat dilihat saat mereka sedang mengadakan pelatihan atau workshop kesenian dan kerajinan tangan untuk wisatawan dan warga RW 03. Warga yang memiliki keahlian dibidang tersebut menyumbangkan keahliannya untuk mengajar dan memberikan materi mengenai kesenian tersebut. Pada pementasan seni atau festival warga juga memberikan sumbangan keahliannya untuk meramaikan acara tersebut. Sumbangan keahlian pada kampung kreatif juga tidak terbatas pada keahlian seni dan kerajinan tangan saja, tapi juga keahlian dalam berorganisasi sebagaimana kampung kreatif Dago Pojok sering bekerja sama dengan pihak lain dalam mengadakan suatu acara sehingga keahlian berorganisasi dan berdiplomasi juga diperlukan dan beberapa warga yang terlibat didalam kepengurusan dapat memberikan keahlian tersebut untuk mendukung pengembangan program kampung kreatif.

Partisipasi barang yang diberikan warga RW 03 juga sudah dilakukan oleh beberapa warga, meskipun tidak seluruh warga memberikan sumbangan berupa barang atau harta yang mereka miliki, sumbangan dari beberapa warga tersebut merupakan hal yang menguntungkan untuk pengembangan program. Seperti misalnya sumbangan tanah dari beberapa warga yang memiliki tanah di RW 03 dan diberikan kepada program untuk dijadikan ruang pementasan sangat membantu program. Dalam skala yang lebih kecil, warga juga banyak menyumbangkan barang-barang bekas seperti botol atau peralatan rumah tangga tak terpakai untuk dijadikan karya seni dan kemudian dipamerkan dalam acara festival. Partisipasi barang dari warga merupakan hal yang bermanfaat bagi kemajuan program karena program kampung kreatif bukan program yang mendapatkan dana secara rutin dari pihak tertentu sehingga sumbangan berupa barang dari warga akan membantu untuk penghematan anggaran yang dimiliki oleh program ketika mengadakan suatu kegiatan.

Partisipasi uang merupakan jenis partisipasi yang paling sedikit dilakukan oleh warga RW 03 karena warga secara keseluruhan belum memiliki kemampuan untuk itu dan program lebih memilih untuk menghimpun dana dari luar RW 03 meskipun penghimpunan dana keluar juga dijalankan oleh warga bersama dengan pengurus. Tidak banyak warga yang memberikan partisipasi uang, hal ini dikarenakan banyak warga yang merasa belum mampu memberikan banyak sumbangan uang untuk program dan program juga belum memiliki sistem iuran dari warga yang dapat membantu keuangan program.

\section{Saran}

Berdasarkan dari fenomena di lapangan yang telah diungkapkan dan dibahas sebelumnya, peneliti akan memberikan saran untuk membuat partisipasi masyarakat dalam pengembangan program kampung kreatif Dago Pojok dapat berjalan dengan lebih baik dan memberikan dampak yang lebih baik juga bagi keberlangsungan program. Yaitu program pengumpulan dana atau fundraising. Salah satu jenis partisipasi warga yang kurang dominan 
dalam pengembangan kampung kreatif Dago Pojok adalah partisipasi dalam bentuk uang. Partisipasi dalam bentuk uang merupakan salah satu hal yang dibutuhkan karena dalam melaksanakan kegiatan-kegiatan yang mendukung pengembangan kampung kreatif, program memperoleh dana dari hasil mencari sponsor saat hendak mengadakan kegiatan dan tidak mendapatkan dana rutin dari pemerintah maupun lembaga lainnya. Seperti yang telah dikatakan peneliti pada bagian saran, partisipasi uang dapat digantikan dengan jenis partisipasi lainnya seperti misalnya warga dapat memberikan pemikiran, tenaga dan keahlian dalam bidang organisasi untuk menjalin kemitraan dengan lembaga atau perusahaan yang dapat mendukung pendanaan program secara rutin. Dengan adanya usaha untuk menggalang dana dari warga, partisipasi warga pun semakin teruji sebagaimana mereka mampu mengakali kekurangan pada salah satu jenis partisipasi dan dengan adanya pemasukan dana yang lebih banyak, program dapat menjalankan kegiatan-kegiatannya lebih rutin dan lebih baik lagi.

\section{DAFTAR PUSTAKA}

Adi, Isbandi Rukminto. 2003. Pemberdayaan, Pembangunan Masyarakat dan Intervensi Komunitas: Pengantar pada pemikiran dan pendekatan praktis. Jakarta: FE UI.

Burhan, Bungin, 2007. Penelitian Kualitatif: Komunikasi, Ekonomi, Kebijakan Publik, Dan Ilmu Sosial Lainnya. Jakarta: Kencana

Carry, J Lee. 1970. Community Development as a Process. Columbia: University of Missouri Press

Cresswell, John W. 1994. Research Design: Qualitative and Quantitative Approaches. New York: Sage Publications.

Dunham, Arthur. 1957. Community Welfare Organization, Thomas Y Corwell.

Fahrudin, Adi. 2011. Pemberdayaan, Partisipasi \& Pengembangan Kapasitas Masyarakat. Bandung: Humaniora.
Hadiwijoyo, Surya Sakti. 2012. Perencanaan Pariwisata Perdesaan Berbasis Masyarakat. Yogyakarta Graha Ilmu. Hermantoro, Hengky, 2011. Creative-based tourism : Dari wisata rekreatif menuju wisata kreatif. Aditri.

Ife, Jim, 1995. Community Development: Creating Community Alternatives : Vision, Analysis, and Practice. Longman.

Ife, Jim. 2008. Community Development: Alternatif Pengembangan Masyarakat di Era Globalisasi. Yogyakarta: Pustaka Pelajar.

Iskandar, Jusman. 1994. Strategi Dasar Membangun Kekuatan Masyarakat. Jakarta: Rajawali

Ismawan, Bambang. 2003. Partisipasi dan Dimensi Keswadayaan: Pengalaman LSM Membangun Keswadayaan Masyarakat. Jakarta:Puspa Swara

Karianga, Hendra. 2011. Partisipasi Masyarakat Dalam Pengelolaan Keuangan Daerah: Perspektif Hukum dan Demokrasi. Bandung: Alumni.

Munandar, Utami. 1999. Pengembangan kreativitas anak berbakat. Jakarta: Rineka Cipta

Nirwandar, Sapta. 2014. Building Wow: Indonesian Tourism \& Creative Industry. Jakarta: PT Gramedia Pustaka Utama.

Sastropoetro, Santoso. 1986. Partisipasi, komunikasi, persuasi dan disiplin dalam pembangunan nasional. Bandung: Alumni

Spillane, James J. 1987. Ekonomi Pariwisata, Sejarah dan Prospeknya. Yogyakarta: Kanisius

Suharto, Edi. 2010. Membangun Masyarakat Memberdayakan Rakyat: Kajian Strategis Pembangunan Kesejahteraan Sosial \& Pekerjaan Sosial. Bandung: Refika Aditama

Sugiyono. 2007. Metode Penelitian Administrasi. Bandung: Alfabeta 